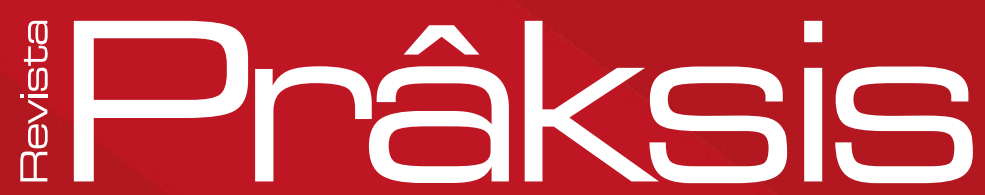

Recebido em: 28 de fevereiro de 2018

Aprovado em: 13 de junho de 2018

Sistema de Avaliação: Double Blind Review

RPR |a. 15 | n. 2 | p. 84-100|jul./dez. 2018

DOI: https://doi.org/10.25112/rpr.v2i0.1646

\title{
DESDE A CELA DO PRESO \\ POLÍtico: OS DIÁRIOS DO \\ DOMINICANO FERNANDO \\ DE BRITO
}

FROM THE CELL OF THE POLITICAL

PRISONER: THE DIARIES OF THE

DOMINICAN FERNANDO DE BRITO

\section{Regina Zilberman}

Doutora em Romanistica (Universidade de Heidelberg/Alemanha).

Professora na Universidade Federal do Rio Grande do Sul (Porto Alegre/Brasil).

E-mail: reginaz@portoweb.com.br. 


\section{RESUMO}

O Diário de Fernando (2009), editado por Frei Betto a partir das anotações do dominicano Fernando de Brito, pertence ao gênero da literatura carcerária que, remontando ao Críton, de Platão, tem em Memórias do cárcere (1953), de Graciliano Ramos, seu principal paradigma brasileiro. Ao examiná-lo, apresenta-se sua integração ao gênero, o testemunho do autor sobre a vida política brasileira entre o final dos anos 1960 e começo dos anos 1970, e os processos de repressão de que foram vítimas o religioso e seus companheiros de cela.

Palavras-chave: Literatura carcerária. Diário. Memorialismo. Fernando de Brito. Frei Betto.

\section{ABSTRACT}

The Diário de Fernando (2009), edited by Frei Betto from the notes of the Dominican Fernando de Brito, belongs to the genre of prison literature, which, dating back to Plato's Crito, has in Graciliano Ramos' Memórias do cárcere (1953) his main Brazilian model. By examining it, we can identify its integration to the genre, the author's testimony on the Brazilian political life between the late 1960s and early 1970s, and repression processes that have suffered the Domincan and his cellmates.

Keywords: Prison literature. Journal. Memorialism. Fernando De Brito. Frei Betto. 


\section{A PALAVRA CONFINADA}

Relatos da prisão, enunciados na voz de presos políticos, talvez remontemà Antiguidade, se conferirmos ao Críton (PLATÃo, s. d.) de Platão o papel de narrativa fundacional. Transcorrido nas masmorras de Atenas, o diálogo reproduz o empenho de Críton, amigo de longa data de Sócrates e seu admirador, em ajudá-lo a evadir-se do local, escapando da execução da pena por envenenamento, programada para o dia seguinte. $O$ filósofo recusa a colaboração, preferindo a morte digna à hipótese de ser posteriormente acusado de burlar a lei e ferir a justiça.

Ao submeter-se aos ditames dos juízes atenienses, Sócrates não está reconhecendo a culpa; pelo contrário, considera-se inocente. Mas coloca a lei e o exercício da justiça acima dos julgamentos individuais - a opinião (doxa), segundo ele -, de modo que só lhe cabe aceitar a sentença que o condena ao suicídio induzido. 0 posicionamento é controverso, porque sugere nas entrelinhas que a justiça paradoxalmente pode ser injusta, sobretudo se o indivíduo tiver sido encarcerado por razões políticas, o que não o transforma em um criminoso a não ser para as instâncias que controlam o poder.

Críton não é um relato memorialista, mas um diálogo, gênero em que o discurso se desenvolve no presente e na atualidade dos falantes. Na trajetória de uma história da literatura desde a perspectiva dos detentos que puderam oferecer seu depoimento relativamente à sua condição de prisioneiros, 0 lugar do memorialismo é ocupado por Recordações da casa dos mortos, que F. Dostoiévski (DOSTOIÉVSKI, 1961) publicou, primeiramente sob a forma de crônica jornalística, a seguir em livro, entre 1861-1862. 0 título antecipa a inscrição no gênero memorialista; por sua vez, a circunstância de que o autor dá conta do período em que esteve preso na Sibéria, acusado de pertencer a um grupo considerado subversivo, coloca-o na posição de preso político. Ainda que a narrativa não privilegie apenas a perspectiva pessoal do narrador, preferindo incluir acontecimentos vinculados à situação dos outros cativos, Recordações da casa dos mortos constitui-se em obra canônica do gênero, repercutindo intensamente em escritores que relembram seus tempos de encarceramento.

Nem todos os registros de encarceramento optaram pelo formato memorialista. Oscar Wilde, em De Profundis [1897], vale-se do gênero epistolar, empregado igualmente por Antonio Gramsci em Cartas do cárcere, enquanto que $A$ balada do cárcere de Reading [1897], também de Oscar Wilde, é um poema. De teor ficcional é Um dia na vida de Ivan Denisovich [1962], de Alexander Soljenítsin, que, em 1973, publica o documental Arquipélago Gulag, apoiado na experiência do autor nos campos de trabalhos forçados na União Soviética. Direta ou indiretamente, obras como essas estabelecem um padrão de representação do universo carcerário e um modo de exposição, predominantemente em primeira pessoa, apontando para o caráter testemunhal da escrita. No Brasil, foram as Memórias do cárcere, de Graciliano Ramos, que 
definiram a forma de expressão mais acabada ao gênero. Leitor de Dostoiévski, citado no texto, o escritor converte-se, ele mesmo, na memória - ou o paradigma - dos processos de narração de um período de encarceramento.

\section{GRACILIANO RAMOS NA “CASA DOS MORTOS"}

Antes do livro de Graciliano, publicado originalmente em quatro volumes em 1953, poucos autores brasileiros abordaram o tema do encarceramento. Dois deles relataram o tempo em que foram cativos da Inquisição: o jesuíta Antônio Vieira (nascido em Portugal mas residente por longo tempo na colônia americana) que, nas Notícias recônditas do modo de proceder a Inquisição de Portugal com seus presos [1675?], denuncia os horrores a que eram submetidas as vítimas do Santo Ofício, ele mesmo tendo sido uma delas entre 1665 e 1667; e Hipólito da Costa que, na Narrativa da perseguição [1811], relata, na forma do diálogo socrático, o modo como foi detido e o processo de que foi objeto, em 1799. Também do período colonial provém o depoimento de Tomás Antônio Gonzaga que, nos poemas de Marilia de Dirceu [1792-1812], lamenta sua sorte em comoventes versos dirigidos à amada, a exemplo da Lira XXII, da Segunda Parte do livro (GONZAGA, 1961, p. 121):

$$
\begin{aligned}
& \text { Por morto, Marília, } \\
& \text { aqui me reputo: } \\
& \text { mil vezes escuto } \\
& \text { o som do arrastado, } \\
& \text { e duro grilhão. } \\
& \text { A chave lá soa } \\
& \text { na porta segura: } \\
& \text { abre-se a escura, } \\
& \text { infame masmorra } \\
& \text { da minha prisão. }
\end{aligned}
$$

Antônio Vieira, como futuramente Fernando de Brito, é um religioso que desagrada o poder constituído; Tomás Antônio Gonzaga, como depois o dominicano, é prisioneiro político, acusado de pertencer a um grupo de letrados que almejavam emancipar o território brasileiro - ou ao menos a porção que correspondia às Minas Gerais - da metrópole portuguesa. Século e meio depois, é Graciliano Ramos o alvo da incriminação, o que o leva a percorrer uma via crucis pelos cárceres do Nordeste e do Rio de Janeiro.

O ano é 1936, e o Brasil é governado por Getúlio Vargas que, em 1930, liderara um movimento contrário à posse de Júlio Prestes, vencedor do pleito realizado naquele ano para a presidência da República. Depondo com alguma facilidade Washington Luís, então ainda ocupante da cadeira presidencial, o político 
sulino tomara seu lugar, em que se mantinha apesar de reações contrárias provindas sobretudo de São Paulo, local de uma rebelião civil que, em 1932, exigira o estabelecimento de uma Assembleia Nacional Constituinte e a realização de eleições gerais.

Ainda que derrotados, os revoltosos constitucionalistas de São Paulo alcançam a concretização de algumas de suas metas: instala-se a Assembleia Constituinte, e nova Constituição é promulgada. Porém, adota-se a eleição indireta para a presidência, e Vargas obtém novo mandato de quatro anos. A insatisfação intensifica-se, levando intelectuais e líderes políticos a se organizarem, em 1935, em uma associação não declaradamente partidária, a Aliança Nacional Libertadora (ANL). No mesmo ano, oficiais do exército, lotados em Natal e Recife, tomam quartéis, no esforço de dar início a uma revolução socialista; no Rio de Janeiro, o movimento se repete, com participação de filiados ao Partido Comunista, entre os quais, Luís Carlos Prestes. Vargas aproveita o momento político de instabilidade e decreta a Lei de Segurança Nacional, que the confere plenos poderes para prender pessoas acusadas de cooperar com a tentativa de derrubar o governo, colocando na cadeia militares acusados de insurreição, além de comunistas e escritores simpatizantes das esquerdas. Entre eles, constava Graciliano Ramos, na época, "funcionário na instrução pública de Alagoas" (RAMOS, 1954, v. 1, p. 11).

Graciliano foi preso em março de 1936, sem ter sido formalizada a acusação que justificaria 0 encarceramento; também não foi julgado, datando sua soltura de 13 de janeiro de 1937. Ficou detido primeiramente em um quartel de Maceió, depois em Recife, de onde partiu a bordo do navio Manaus para o Rio de Janeiro, ao lado de outros incriminados por razões políticas. Na então capital da república, permaneceu no início no Pavilhão dos Primários, depois foi deslocado para a Colônia Correcional de Dois Rios, de onde retornou para a Casa de Correção, no Rio de Janeiro, até ser liberado sem que se tenham esclarecido juridicamente os motivos para sua permanência, por quase um ano, naqueles presídios.

É bem depois desses acontecimentos, "casos passados há dez anos" (RAMOS, 1954, v. 1, p. 5), que o escritor alagoense, já então aclamado por livros como Angústia [1936] e Vidas secas [1938], enceta a redação de suas Memórias do cárcere. A se julgar pela declaração constante nas primeiras linhas do capítulo de abertura, o processo principia em $1946 ;^{1}$ porém, a publicação dos volumes, ainda que inacabado o último, ocorre postumamente em 1953. A obra, portanto, pressupõe dois grandes intervalos temporais: entre a liberação, em 1937, e o início da escrita das recordações do tempo da prisão, e entre esse começo e o lançamento do texto impresso. 0 primeiro intervalo soma quase dez anos, e o segundo, pelo menos sete, na hipótese de que Graciliano estivesse em vias de concluir seu trabalho.

\footnotetext{
${ }^{1}$ Ramos (1992) e Lebensztayn (2014).
} 
Os gaps cronológicos são, eles mesmos, bastante significativos, pois sinalizam a dificuldade de elaboração, por parte do escritor, do trauma do encarceramento. Graciliano Ramos provavelmente só se sentiu à vontade para evocar os tempos de cadeia, quando o Brasil atravessava nova etapa histórica, após a destituição de Getúlio Vargas e a realização de eleições democráticas, entre 1945 e 1946. Mesmo assim, o processo de redação deve ter sido penoso, pois o ficcionista, tão bem-sucedido em outros relatos memorialistas, de que é exemplo Infância [1945], não alcançou terminar o livro, quando teria de traduzir a nova situação de liberdade, após a saída da prisão, em 1937. De certo modo, talvez se possa dizer que o autor nunca conseguiu deixar o cárcere, pois não teve condições de narrar o fato. É de se cogitar que essa lacuna provavelmente estimulou Silviano Santiago a escrever o romance Em liberdade [1981], em que imagina o diário escrito por Graciliano ao sair da prisão, em janeiro de 1937. 0 primeiro registro da ficção imaginada por Santiago data de 14 de janeiro (SANTIAGO, 1981, p. 27) e parece responder às páginas finais da Memórias do cárcere, em que o escritor comenta em curto diálogo: "- Que é que você pretende com o último capítulo? / Sensações da liberdade" (RAMOS, 1954, v. 4, p. 161).

A impossibilidade de entender-se livre e expressar a autonomia adquirida importa o evento do passado para o presente do escritor. É como se o memorialista fosse substituído pelo autor de um diário, pois, ao falar do que aconteceu, o narrador refere-se igualmente ao que permanece ocorrendo consigo mesmo. 0 trauma parece não ter sido superado, o que, à sua maneira, aprisiona o sujeito da enunciação dentro de si, dando voltas em seu inconsciente. Sob esse aspecto, Memórias do cárcere antecipa o Diário de Fernando naquilo em que esse dá conta de um presente igualmente contínuo, uma vez que os registros do dominicano são transferidos para a atualidade por meio de Frei Betto, seu editor.

Outros aspectos aproximam as duas obras, posicionando Memórias do cárcere como a grande árvore que faz sombra sobre seus sucessores. Um deles diz respeito à expressão do espaço sufocante da prisão, destacando-se os que, na obra de Graciliano Ramos, apresentam o porão do navio Manaus, que transporta os detentos para o Rio de Janeiro, e os ambientes da Colônia Correcional de Ilha Grande. Elucidam o significado da "masmorra", tópico que, presente desde o Críton, de Platão, transita pela literatura nos textos de Antônio Vieira, Tomás Antônio Gonzaga, Hipólito da Costa e Graciliano Ramos, até chegar às páginas do diário de Fernando.

Decisiva é também, considerando a poética do confinamento, a narrativa em primeira pessoa, ainda quando essa não se refira exclusivamente ao sujeito responsável pela escrita. Alinhando-se, prospectivamente no caso das Memórias do cárcere, à literatura de testemunho, as obras almejam alcançar credibilidade e verossimilhança, porque o narrador fala do que the aconteceu. Não the cabe provar algo, mas apenas depor, o que pode suscitar suspeita ou rejeição. Mas aceita-se a sinceridade das declarações, 
porque se trata de um discurso confessional, logo, autêntico. Além disso, generoso, porque o eu que se manifesta não restringe o testemunho a si próprio, expondo o que se passa com outros, cuja sorte seguidamente pode ser ainda pior. Completa o paradigma da autenticidade a circunstância de que esses "outros" não são personagens produzidas pela imaginação do autor, mas personalidades históricas, menos ou mais conhecidas pelo leitor, ${ }^{2}$ que, assim, por experiência ou por pesquisa retrospectiva, poderá validar a exposição do narrador.

\section{OUTRAS MEMÓRIAS DO CÁRCERE}

Fernando de Brito, junto com os dominicanos Betto (Carlos Alberto Libânio Christo), Tito de Alencar Lima e Ivo Lespaubin, foi encarcerado em novembro de 1969 nas dependências do Deops, e depois transferido para outras prisões situadas na cidade e no estado de São Paulo - Presídio Tiradentes, Penitenciária do Estado e Carandiru, Penitenciária de Presidente Venceslau - datando de outubro de 1973 a soltura de três deles (meses antes, Tito de Alencar Lima constara da lista de presos políticos banidos do país, em troca da liberdade do diplomata suiço Giovanni Enrico Bucher). Durante esse período de quatro anos, Fernando redigiu as interditadas páginas do diário que, de modo habilidoso, conseguiu enviar para fora das grades. A divulgação desse material não ocorreu imediatamente: o material somente se tornou público em 2009, após cuidadoso trabalho de seleção e edição executado por Betto, autor também da introdução e do epílogo da obra.

Por decorrência dessa situação, o texto compartilha uma dupla condição, para além da circunstância de dispor de dois autores, Fernando e Betto, ambos identificados na capa: trata-se de um diário e, como tal, foi elaborado no calor dos acontecimentos experimentados pelos detentos políticos; mas é igualmente uma obra de memórias, pois supõe um arco de 40 anos entre o primeiro registro, de novembro de 1969, e o lançamento do livro, pela Rocco. Levada em conta a data em que Betto assina a introdução - 4 de novembro de 2008 -, a conta diminui para 39 anos; por outro lado, a identificação do dia em que a apresentação foi escrita sinaliza a intenção de fechar um ciclo, o novembro de Fernando enlaçando-se com o novembro de Betto. E, mesmo que se considere o ano de 2005, quando Betto "assume a tarefa de transformar os diminutos alfarrábios de Fernando - alguns a exigirem o auxílio de lentes de aumento em obra literária" (BETTO, 2009, p. 13), ainda assim se erguem mais de três décadas a separar o final do diário e o início da preparação dos originais pelo ex-parceiro de cárcere.

\footnotetext{
2 Podem-se citar, entre as pessoas lembradas por Graciliano Ramos, Agildo Barata e Rodolfo Ghioldi, entre os homens; Olga Benário Prestes, Nise da Silveira e Eneida de Moraes, entre as mulheres; José Lins do Rego e Sobral Pinto, entre os intelectuais então residentes no Rio de Janeiro que procuraram ajudar o escritor.
} 
A distância temporal desloca, pois, o Diário de Fernando para o paradigma das memórias, sem renunciar à condição original do gênero identificado no título, e essa é a primeira de suas particularidades. A segunda é sua inserção à prática militante de religiosos brasileiros pouco antes e logo depois do golpe civil-militar de 1964.

\section{BRASIL FORA DAS CELAS}

Os quatro dominicanos que protagonizam o Diário de Fernando foram presos em novembro de 1969, "por apoiarem movimentos de guerrilha urbana, em especial a Ação Libertadora Nacional (ALN), comandada por Carlos Marighella" (BETTO, 2009, p. 11), conforme informa Frei Betto na primeira página do livro. As ações de oposição ao governo militar, no poder desde março de 1964, haviam-se agudizado depois da posse de Artur da Costa e Silva na presidência da República, quando ficou evidente que o Exército não pretendia devolver a gerência do Estado aos civis. Em 1968, manifestações e passeatas de estudantes, protestos dos intelectuais e artistas, pronunciamentos de contrariedade de membros da oposição na Câmara de Deputados servem de pretexto para a promulgação do Ato Institucional 5 (Al-5), que fecha o Congresso Nacional, impede o habeas corpus, institui a censura prévia e suspende os direitos políticos.

Em 1969, os grupos de esquerda mudam a estratégia de ação, alguns segmentos optando pela guerrilha urbana, outros pela guerrilha rural, de que é exemplo a do Araguaia, liderada pelo Partido Comunista e que teve entre seus líderes Carlos Lamarca, cuja morte é lembrada por Fernando em registro de agosto de 1971 (BETTO, 2009, p. 154). As duas orientações pautavam-se por teses distintas relativas às possibilidades de derrubar o governo e alterar o modelo político, e mesmo entre elas, discordâncias se apresentavam. Carlos Marighella conduzia a ALN, o que não impediu a dissidência que formou o Movimento Popular de Libertação Nacional (MOLIPO), nem as atividades do Movimento Revolucionário 8 de Outubro (MR-8), da Vanguarda Armada Revolucionária Palmares (VAR-Palmares) e da Vanguarda Popular Revolucionária (VPR), agregando militantes que operavam clandestinamente no Brasil do final dos 1960/início dos 1970.

O Estado mostrava-se bem instrumentalizado para o combate aos bolsões de resistência. Aliado aos governos também direitistas do Cone Sul (Argentina, Paraguai e Uruguai, a que se somou, após setembro de 1973, o do Chile), e recebendo tecnologia e assessoria fornecida pela norte-americana Agência Central de Inteligência (CIA), os militares contavam com órgãos de investigação e informações equipados, além de dispor de licença, por meio de policiais, para praticar a tortura, independentemente da condição física, mental ou jurídica de suas vítimas. Em São Paulo, é o Departamento Estadual de Ordem Política e Social de São Paulo (DEOPS), a "polícia política," como sintetiza Fernando (BETTO, 2009, p. 16), a entidade 
encarregada da acolhida, obtenção das informações e distribuição dos presos políticos, entre os quais os dominicanos que comparecem no Diário de Fernando.

O período em que eles permanecem presos, de novembro de 1969 a outubro de 1973, corresponde inteiramente aos chamados "anos de chumbo", subsequente ao afastamento de Costa e Silva da presidência. Vítima de acidente vascular-cerebral em agosto de 1969, o marechal fora retirado do cargo, mas o vice-presidente, um civil, não pôde substituí-lo, sendo a posição ocupada por uma Junta Militar, a seguir pelo general Emílio Garrastazu Médici. No período de vacância da presidência, não, porém, de vácuo do poder, realiza-se o primeiro dos sequestros de diplomatas estrangeiros: o embaixador dos Estados Unidos é feito cativo de militantes do MR-8 e da ALN, e posteriormente trocado por quinze prisioneiros políticos, liberados em setembro de 1969 e banidos do Brasil. Outros sequestros sucedem-se nos meses seguintes, com as consequentes negociações em prol da soltura de presos, ao lado de iniciativas como assaltos a bancos e organizações financeiras, que, aos poucos, porém, são contidas pelo Exército e pela polícia, com a ajuda dos serviços norte-americanos de contraespionagem.

No Diário de Fernando, relatam-se os efeitos das ações político-revolucionárias, que facultaram a liberação de Madre Maurina (BETTO, 2009, p. 90), em março, e de Tito de Alencar Lima, em dezembro de 1970: "Frei Tito, incluído na lista dos sequestradores; já assinou o termo de banido do Brasil," registra sumariamente Fernando (BETTO, 2009, p. 138).

\section{A IGREJA DIZ PRESENTE}

A luta armada desenha o pano de fundo laico das anotações do dominicano. Ao lado dela, colocase o panorama político-religioso, decorrente, em primeiro lugar, da condição sacerdotal do redator do diário e de seus companheiros, Tito, Ivo e Betto, também eles militantes da causa revolucionária e cujo aprisionamento requereu uma tomada de posição por parte da Igreja nacional e do Vaticano.

A Igreja brasileira, até a segunda metade do século $X X$, não se notabilizara por feitos políticos progressistas. Ao final do segundo reinado, a questão religiosa opusera o imperador Pedro II e os bispos católicos, que, ultramontanos, julgavam dever obediência tão somente às medidas emanadas da sede, em Roma. À época da República Velha e, depois, por ocasião da redemocratização subsequente à queda de Getúlio Vargas, pedagogos e intelectuais de orientação católica buscaram garantir a permanência do ensino religioso na educação básica, ainda que o Estado fosse laico, e a escola, pública. Menos progressista foi ainda o posicionamento do clero nos meses que antecederam à derrubada de João Goulart pelos militares. No primeiro semestre de 1964, as Marchas da Família com Deus pela Liberdade reuniram multidões nas maiores cidades brasileiras, evidenciando o poder de mobilização dos clérigos, apoiando posições das classes médias urbanas. 
A essas alturas, porém, o Vaticano, sob a batuta de João XXIII, tomava outro rumo. O Concílio que promoveu, entre 1962 e 1965, buscou refletir sobre o papel da Igreja no contexto das transformações sociais e econômicas que se sucederam ao final da segunda guerra mundial, ao processo de descolonização na África e às lutas pela emancipação política e econômica em regiões da América e da Ásia. A Teologia da Libertação, enunciada também nos anos 1960, foi um dos efeitos da atitude renovada da Igreja, agora vocacionada para os pobres e as vítimas da exploração e da desigualdade. Em 1968, reunido em Medelín, 0 Conselho Episcopal Latino-Americano (CELAM) encaminhou diretrizes visando à aproximação dos padres aos problemas experimentados pelos trabalhadores urbanos e rurais do continente, resultando desse projeto a criação das Comunidades Eclesiais de Base (CEBs), locais de reunião, bem como de discussão e prática, de uma ação política junto às camadas populares.

A Igreja não se limitou a alterar sua atuação junto ao clero, tomando também a iniciativa de estimular organizações habilitadas a congregar ideário religioso e ação política transformadora e progressista, projeto que deu origem a associações como a Juventude Operária Católica (JOC), focada nos trabalhadores, a Juventude Estudantil Católica (JEC) e a Juventude Universitária Católica (JUC), essas orientadas para os estudantes.

Fernando de Brito narra, em um dos registros iniciais do diário, sua participação nos movimentos cristãos, lembrando quando "travou amizade com dois militantes da Ação Católica" (BETTO, 2009, p. 24), antes mesmo de sua opção por aderir à Ordem dominicana, em 1956. Sua formação começa, pois, quando principia o movimento de renovação do Clero católico na direção da luta em nome da justiça social. No primeiro registro do diário, que cobre o mês de novembro, quando está preso no Deops, em São Paulo, Fernando expõe as transformações por que passava a Igreja, colocando os dominicanos na liderança do processo de mudança e, assim, articulando sua trajetória pessoal ao que ocorria, em termos de prática política, em âmbito nacional e internacional:

O pontificado de João XXIII e o Concílio Vaticano II vieram sacramentar o pioneirismo dos dominicanos, cuja evangelização descartava o moralismo e valorizava a luta por justiça social.

A formação dos jovens dominicanos, antes confinada ao claustro, estendeu-se à USP. [...] O contato com o movimento estudantil provocaria em nós o mesmo impacto progressista que, no pós-guerra na França, causou a aproximação de parte do clero com o movimento sindical. Nosso ardor apostólico ganhou conotação nitidamente militante; e a pregação do Reino de Deus, uma consistência imediata: a revolução brasileira (BETTO, 2009, p. 30).

Na segunda metade dos anos 1960, a militância, que é apostólica, depara-se com os efeitos do golpe militar no Brasil, que, embora se intitule revolucionário, toma decisões conservadoras, antipopulares e submissas 
aos interesses norte-americanos. 0 idealismo dos sacerdotes não bastaria para conter o retrocesso, o que estimula a mudança de tática, determinando o ativismo que Fernando de Brito expressa, pois, ao lado dos parceiros de cela, compromete-se, a partir de 1967, com os "revolucionários marxistas" (BETTO, 2009, p. 32), liderados por Carlos Marighella, desempenhando missões como as que descreve no Diário:

O trabalho dos frades na ALN consistia em favorecer o desabrochar da luta armada. Base de apoio de militantes envolvidos em expropriações bancárias, sequestros, bombas, etc., acolhíamos feridos e perseguidos, facilitando-Ihes a recuperação e a fuga do país; escondíamos armas e material considerado subversivo; fazíamos o levantamento de áreas potencialmente adequadas ao desencadeamento da guerrilha rural. Pau pra toda obra, só não apertamos o gatilho (BETTO, 2009, p. 32)

Fernando narra também o final de sua ligação com a ALN, na esteira da perseguição, movida pelas forças de repressão aos envolvidos no sequestro do embaixador norte-americano, em setembro de 1969. Frei Ivo e ele são presos em $1^{\circ}$ de novembro de 1969, no Rio de Janeiro; torturados, os dois confessam o pouco que sabem, o que ajuda a polícia a localizar Carlos Marighella em São Paulo, armar uma cilada tendo os dois frades como isca, e assassiná-lo em 4 de novembro. 0 peso da culpa abate Fernando, porque, direta ou indiretamente, colaborou com os investigadores, o que o impele a expor os acontecimentos no esforço de alcançar a remissão.

O registro de abertura do Diário tem, pois, intuito não apenas retrospectivo, mas redentor: Fernando precisa verbalizar o que aconteceu para superar a autoincriminação. Os policiais que caçaram Marighella, com o fito de atormentá-lo e abalar sua autoestima, acusam-no de "traidor", mas não é esse o comportamento dos companheiros de cela: "ninguém nos acusou de 'traidores'" (BETTO, 2009, p. 41). A reação dos amigos, contudo, tem como consequência o aumento da culpa e o sentimento de fracasso:

Aquele silêncio, entretanto, me feriu como benevolência indevida. Era muito grave o ocorrido e eu fora peça importante no êxito da emboscada que eliminou o líder revolucionário. Talvez a acusação de 'traidor' por parte dos companheiros ajudasse a objetivar em culpa a sensação de derrota que me vergava os ombros. Mas ela não veio; e tive que aprender a conviver com o peso indefinido da humilhação de ter sido manipulado pela polícia (BETTO, 2009, p. 42).

A cena fundadora do Diário da prisão soma indignação decorrente das atrocidades sofridas e culpa advinda da colaboração indesejada. Os frutos da militância não mais lhe parecem benéficos ou promissores, porque a força da repressão policial superou os princípios éticos e ideológicos, assim como a boa vontade de seus praticantes. É quando começa a nova fase dessa militância que a remissão parece ter a oportunidade de se reconfigurar. 
Noves fora os quadros que derivaram para a luta armada, foram os sacerdotes brasileiros os que mais explícita e eficientemente rejeitaram o regime político imposto pelos militares a partir dos anos 1970. Símbolo da resistência foi primeiramente Helder Câmara, arcebispo de Olinda e Recife, que, em plano nacional, com repercussão internacional, denunciou as práticas autoritárias e o desrespeito dos direitos humanos pelo então governo do país. Entidade igualmente dinâmica foi a Confederação Nacional dos Bispos do Brasil (CNBB), presidida, a partir de 1971 e por toda aquela década, por Aloísio Lorscheider. Nesse contexto, destaca-se também a ação de Paulo Evaristo Arns, dedicado à defesa dos direitos humanos, de que resultaram a criação da Comissão Justiça e Paz de São Paulo e, mais adiante, a denúncia dos desaparecidos políticos nas décadas de 1960 e 1970.

Não surpreende, pois, a presença desses padres nas páginas do Diário de Fernando, que sinalizam a resposta da Igreja, representada aqui por seus líderes, à prisão, tortura e sevícias a que são submetidos os sacerdotes detidos, a ponto de alcançar a manifestação do Papa Paulo VI. É a mobilização coletiva, aliada às denúncias na imprensa estrangeira, que dimensiona a situação dos dominicanos, particularizando-a no contexto dos prisioneiros políticos que dividem com eles as celas dos cárceres paulistas.

A produção do diário por Fernando pode ser, pois, entendida como a contrapartida às cartas da prisão, enviadas clandestinamente por Betto ao exterior, publicadas originalmente na Itália, depois difundidas na França, até serem lançadas no Brasil em 1976 (BETTO, 2009, p. 144). Por isso, Fernando não apenas redige um diário, mas precisa enviá-lo para fora das grades, valendo-se de artimanhas para evitar que seus papéis sejam descobertos ou revelados seus portadores. Impossibilitados de contato com o mundo exterior, exceto em ocasionais visitas de familiares, os detentos não abrem mão da hipótese de se comunicar com o outro lado das muralhas das prisões, evidenciando seu empenho em dar continuidade a seu compromisso político, mesmo que em condições desfavoráveis.

Betto parece ter sido mais bem-sucedido que Fernando, pois não apenas lançou sua correspondência, como teve oportunidade de produzir alguma crônica, como a que é interpolada ao registro de maio de 1972 (BETTO, 2009, p. 192-200). Essa diferença talvez se deva, porém, à opção de Betto pela literatura, o que não se passou com o parceiro de Ordem. Por outro lado, a matéria que Fernando de Brito produziu deu, também ela, margem à proposição de um livro, que, por se guiar pela poética do confinamento que marca a criação de seus antecessores, não deixa de se configurar como obra literária.

\section{LITERATURA CARCERÁRIA E POÉTICA DO CONFINAMENTO}

No texto com que introduz o diário de Fernando, Frei Betto chama a atenção para o trabalho de preparação do material original. Confessa que, ao assumir a tarefa de "transformar os diminutos alfarrábios de Fernando [...] em obra literária," obrigou-se, de uma parte, a cortes, de outra, a acréscimos 
de "notas explicativas [que] figuram no pé da página" (BETTO, 2009, p. 13). Mas considera válidas as providências, porque facultam ao leitor dispor de um "documento" provindo "do testemunho de um preso político, de uma vítima da ditadura, de um observador atento que não ergueu barreiras entre o que presenciou e sentiu, sofreu, ansiou e comemorou" (BETTO, 2009, p. 14).

Betto é bem econômico ao expor o processo de produção do livro, minimizando suas interferências. Fernando parece ocupar de modo soberano a posição de sujeito da enunciação; porém, à medida em que se sucedem os registros, percebe-se, em suas entrelinhas, a onipresença de Betto: introduzem-se textos de sua autoria, seus problemas de saúde são comentados, o sucesso de seu livro contendo a correspondência da prisão é lembrado, e assim sucessivamente.

O frade-escritor não se adona da obra, mas também não se apaga diante dela, revelando-se mais que um editor, o que justifica por que o livro traz seu nome na capa. Fernando acaba por ficar obscurecido diante desse segundo autor, indicando a dualidade da obra que, se já transitava entre dois tempos, oscila agora entre dois sujeitos.

A produção do livro distingue-a, pois, de seu precursor mais renomado, Memórias do cárcere, com o qual, porém, em outros aspectos, divide características. Também aqui a verossimilhança é garantida pela nomeação de várias personalidades conhecidas com que os frades compartilhavam o espaço carcerário, na condição de presos (Caio Prado Júnior, Jacob Gorender, Betinho) ou de algozes, sendo Sérgio Paranhos Fleury provavelmente o mais renomado. ${ }^{3} \mathrm{E}$, tal como no relato de Graciliano Ramos, os detentos são transferidos de uma prisão a outra, como maneira de enfraquecê-los e dobrá-los. A alimentação precária, a falta de higiene e de iluminação, a mistura com os presos comuns (os corrós, na nomenclatura do cárcere), as rotinas dos faxinas, o suborno de carcereiros em troca de comida, cigarros ou favores, as reuniões do coletivo, as palestras educativas - eis toda uma gama de comportamentos e práticas que migram de um livro a outro não apenas porque fazem parte do cotidiano carcerário, mas também do modo de traduzi-lo verbalmente.

\footnotetext{
3 Sérgio Paranhos Fleury (1933-1979) foi delegado do Departamento de Ordem Política e Social (DOPS), de São Paulo, e atuou intensamente na perseguição de opositores do regime entre o final dos anos 1960 e 1970. Ficou conhecido pela prática de tortura e homicídio de presos políticos, bem como por ter participado nos Esquadrões da Morte.
} 
É sob esses aspectos que a obra de Fernando de Brito integra-se não apenas à literatura de testemunho, mas à tradição de exposição do cárcere por meio da linguagem verbal, compartilhando um cânone que dispõe de história particular. Não é que os acontecimentos e hábitos da vida na prisão não tenham ocorrido; mas eles dispõem de um ritual de representação literária que preside não apenas a escolha das palavras, mas seu arranjo em termos de enredo a ser colocado ao alcance do leitor.

0 tratamento que Betto conferiu às anotações de Fernando não dispensou, pois, o andaime que sustenta a elaboração de uma narrativa literária e que se consagrou ao constituir matéria de autores como Dostoiévski e Graciliano Ramos. Não por acaso, no registro de janeiro de 1970, Fernando não resiste à tentação de citar o livro do ficcionista russo: "Fomos todos transferidos do Pavilhão 1 para o 2, cujas instalações recordam a Casa dos Mortos de Dostoiéski" (BETTO, 2009, p. 63). Aqui é o ficcionista que toma a palavra, sugerindo o paradigma a partir do qual almeja ser lido e avaliado. Mais adiante, imiscuise às palavras do sujeito da enunciação o título do romance em que Lima Barreto (BARRETO, 1961) ficcionaliza seu tempo de internamento no Hospital dos Alienados da Praia Vermelha: "A penitenciária parece um cemitério de vivos" (BETTO, 2009, p. 272). Por isso, não poderia faltar o último ato da narrativa carcerária - o encontro com a liberdade.

Relatos verídicos ou ficcionais sobre a experiência do confinamento têm, em princípio, dois tempos como balizas cronológicas: o da detenção, ou aprisionamento, e o da liberação. Recordações da casa dos mortos, que desempenha o papel de paradigma da literatura carcerária, inicia pela chegada do narrador ao presídio e encerra por ocasião de sua saída. Não é muito diferente quando o espaço de confinamento é o hospital psiquiátrico, como em O cemitério dos vivos [1921], de Lima Barreto, ou em Armadilha para Lamartine [1976], de Carlos e Carlos Sussekind (SUSSEKIND, 1991), cujo protagonista é paciente de fictícia casa de saúde situada no bairro de Botafogo, no Rio de Janeiro. Testemunhos de sobreviventes dos campos de concentração acompanham esse modo de exposição, ainda que a recuperação da liberdade nem sempre coincida com algum tipo de júbilo ou alívio, de que é exemplo A trégua [1963], de Primo Levi.

As Memórias do cárcere, de Graciliano Ramos, ainda que se desdobrem por quatro volumes em sua primeira edição, contradizem em parte o procedimento padrão da literatura carcerária, já que se mostram inacabadas. A falta é atribuída ao falecimento do autor, como explica Ricardo Ramos ao final do livro: "Faltava apenas um capítulo destas memórias, quando morreu Graciliano Ramos" (RAMOS, 1954, v. 4, p. 162). Nesse caso, porém, pode-se cogitar que o romancista nunca conseguiu deixar o cárcere e superar o trauma, permanecendo bloqueado no passado, pois são raras, no livro, as referências a fatos históricos ou pessoais acontecidos após 1937. Reduzem-se talvez a uma, apenas: a menção ao destino de Olga Benário Prestes e Elisa Berger, entregues pelo governo de Vargas à Gestapo alemã, para provavelmente 
morrerem em um campo de concentração. Reproduz o narrador o que presumiu à época: "Sentado na cama, pensei com horror em campos de concentração, fornos crematórios, câmaras de gases" (RAMOS, 1954, v. 4, 111), reflexão anacrônica, já que, em 1936, o escritor dificilmente teria conhecimento da "solução final" executada pelos nazistas após 1942.4

Em $O$ Diário de Fernando, as páginas finais são dedicadas ao processo de soltura: em setembro de 1973, o narrador informa a redução da pena de reclusão, originalmente de quatro anos, para dois, após reproduzir o voto de Aliomar Baleeiro, relator do processo; e, em registro de outubro, o último da obra, redigido provavelmente quando já se encontrava em liberdade, anota: "dia 4, festa de São Francisco de Assis, fomos libertados às 9h50" (BETTO, 2009, p. 275). Esclarece, a seguir, terem todos retornado a São Paulo e conclui o livro com um curto parágrafo: "Antes de deixar a penitenciária, fomos aos quatro raios nos despedir de um por um dos presos. E distribuímos a eles nossos pertences" (BETTO, 2009, p. 275).

O parágrafo não coincide, porém, com o final do livro, pois uma nota de rodapé esclarece o destino das personagens cuja sorte o leitor acompanhou ao longo de quase trezentas páginas:

[...] Ivo Lespaupin deixou a Ordem dominicana, formou-se em ciências sociais, casou, teve dois filhos, foi professor universitário no Rio. É assessor de movimentos pastorais e sociais. Frei Betto também assessora movimentos pastorais e sociais, é escritor, e vive hoje no convento dominicano das Perdizes, em São Paulo. Após longos anos de trabalho com a Comissão Pastoral da Terra, no Rio, e em Goiás, eu vivo, hoje, em Conde (BA), dedicado ao diálogo inter-religioso entre a tradição cristã e as tradições africanas. Para atender às necessidades dos jovens, fundei uma Casa de Cultura (BETTO, 2009, p. 275).

\footnotetext{
${ }^{4}$ Boris Schnaiderman observa, a respeito desse trecho, que o pensamento traduzido por Graciliano Ramos "seria impossível em 1936, quando se deu o episódio." (SCHNAIDERMAN, 1995, p. 333). Jacob Gorender igualmente comenta o anacronismo: "Encerrarei com a menção do episódio da expulsão de Olga Benário Prestes e de Elisa Berger e sua posterior entrega pelo governo de Getúlio Vargas e de Filinto Müller à Gestapo. O episódio é contado por Graciliano com sufocante energia narrativa. Quis o acaso que fosse assistido por um escritor à altura, apto a refigurá-lo com sua emoção altíssima. Nesta refiguração, todavia, o narrador incide em anacronismo histórico, carregado de significação. Se me refiro ao anacronismo talvez por motivação ou viés de historiador, não o reduzo a um cochilo de Homero. Graciliano escreve que os presos políticos se uniram no protesto coletivo movidos pelo temor de que enviassem Olga e Elisa à Alemanha, onde, conforme ele próprio pensava, iriam morrer nas câmaras de gás e nos fornos crematórios. Ora, em 1937, já existiam medonhos campos de concentração na Alemanha nazista, porém não câmaras de gás e fornos crematórios. Estes foram inventados em 1940 e utilizados em larga escala somente em 1942, logo depois que Hitler e a cúpula do nazismo aprovaram formalmente a solução final para os judeus. Em 1937, embora já se soubesse do anti-semitismo raivoso dos hitleristas, ninguém fazia idéia dos extremos a que chegariam na prática do genocídio. Como é que Graciliano escreveu que os presos políticos receavam o assassinato de Olga e de Elisa em câmaras de gás e fornos crematórios, dos quais ninguém falava e que, talvez, ainda sequer estivessem na conjectura dos próprios nazistas?" (GORENDER, 1995, p. 329).
} 
A nota faz a ponte entre o passado e o presente, como as anteriores, que, conforme antecipa a Introdução, foram elaboradas por Betto enquanto parte do trabalho de preparação dos originais do livro. O rodapé final, porém, parece ter sido redigido pelo autor do diário, que emprega a primeira pessoa para falar de suas atividades atuais (em 2008-2009), bem como do percurso profissional e acadêmico dos companheiros de infortúnio durante o transcorrer de toda a obra.

Essa nota, portanto, opõe-se à autoria das demais, como se Fernando respondesse às intervenções de Betto em seu texto e, pode-se cogitar, desejasse fazê-lo provar do próprio veneno. Mais surpreendente é a presença do "eu" na derradeira frase, antes do Epílogo assinado por Betto. É essa pequenina, mas significativa, interferência que manifesta, mais do que o último registro, a liberdade de que goza o protagonista.

Ao contrário do que se passa em Memórias do cárcere, em que Ricardo Ramos é chamado, nas páginas de encerramento, a tomar o lugar de Graciliano, seu pai, no Diário de Fernando é o primeiro autor que emerge no presente para dar conta de sua situação contemporânea, mantendo, à sua maneira, pelo menos até a data de lançamento do livro, a militância por que pautou suas escolhas existenciais. Assim, se o registro final, colocado no corpo do texto, aparenta indiferença diante do ato de liberação, a necessidade de retomar os laços com a atualidade e manifestar-se em primeira pessoa une, por outra via, os tempos passado e presente embutidos desde a Introdução no processo de produção do livro, agora, porém, na voz do sujeito de enunciação da escrita primordial.

É ao retomar a palavra e empregar o pronome pessoal de primeira pessoa que Fernando alcança a desejada redenção. Responsável por uma obra nascida de um trauma e, sobretudo, de um sentimento de culpa, o dominicano busca algum tipo de remissão, conquistada não apenas pela ação missionária, mas sobretudo pela liberação de seu discurso, indiretamente ao facultar o trabalho editorial de Frei Betto, diretamente quando opta por dar vazão à própria locução, ainda que no modesto espaço de uma nota de rodapé.

\section{REFERÊNCIAS}

BARRETO, Lima. 0 cemitério dos vivos. 2. ed. São Paulo: Brasiliense, 1961.

BETTO, Frei. Diário de Fernando. Nos cárceres da ditadura militar brasileira. Rio de Janeiro: Rocco, 2009.

DOSTOIÉVSKI, F. M. Recordações da casa dos mortos. Trad. Rachel de Queiroz. Obras Completas e Ilustradas de F. M. Dostoiévski. V. VI. Rio de Janeiro: José Olympio, 1961. 


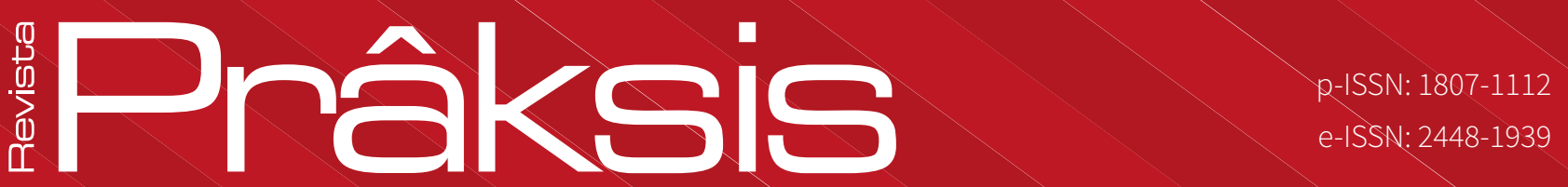

GONZAGA, Tomás Antônio. Marília de Dirceu e mais poesias. 3. ed. Lisboa: Sá da Costa, 1961.

GORENDER, Jacob. Graciliano Ramos: lembranças tangenciais. Revista do Instituto de Estudos Avançados, n. 23, jan./abr. 1995, p. 323-331.

LEBENSZTAYN, leda; SALLA, Thiago Mia (Org.). Conversas. Rio de Janeiro: Record, 2014.

PLATÃO. Critão (Críton), ou o Dever. In: PLATÃO. Diálogos. Tradução de Jaime Bruna. São Paulo: Cultrix, s. d.

RAMOS, Clara. Cadeia. Rio de Janeiro: José Olympio, 1992.

RAMOS, Graciliano. Memórias do cárcere. V. 1. Viagens. 2. ed. Rio de Janeiro: José Olympio, 1954.

RAMOS, Graciliano. Memórias do cárcere. V. 4. Casa de Correção. 2. ed. Rio de Janeiro: José Olympio, 1954.

SANTIAGO, Silviano. Em liberdade. Uma ficção. Rio de Janeiro: Paz e Terra, 1981.

SCHNAIDERMAN, Boris. Duas vozes diferentes em Memórias do Cárcere? Revista do Instituto de Estudos Avançados, n. 23, jan./abr. 1995, p. 332-337.

SUSSEKIND, Carlos \& Carlos. Armadilha para Lamartine. São Paulo: Brasiliense, 1991. 